\title{
Analisis Nilai-Nilai Multikultural pada Buku Teks Pelajaran Agama Katolik dan Budi Pekerti Kurikulum 2013
}

\section{R.F. Bhanu Viktorahadi ${ }^{*}$, Mohammad Taufiq Rahman ${ }^{2}$, Muhtar Solihin ${ }^{3}$}

1 Universitas Katolik Parahyangan Bandung, Indonesia; torahadi@unpar.ac.id

2 UIN Sunan Gunung Djati Bandung, Indonesia; fikrakoe@uinsgd.ac.id

3 UIN Sunan Gunung Djati Bandung, Indonesia; musolihin@yahoo.com

* Correspondence

Received: 2021-02-20; Accepted: 2021-04-12; Published: 2021-04-16.

\begin{abstract}
This study discusses the multicultural value content in the 2013 Textbook of Catholic Religious Education and Curriculum Ethics to describe and analyze various themes and characteristics of multicultural values in the Textbook. Besides, this study also aims to describe and analyze dialectics and how the Catholic Church evangelizes multicultural values in the textbooks discussed. Religious education includes the characteristics and levels of multicultural values that officially reveal the Church to proclaim multicultural values. This study is literature research using content analysis methods, and conceptual analysis approaches to the textbooks discussed. The results showed that there was a multicultural value contained in it. Based on this analysis, this study has two conclusions that summarize the achievement of its objectives. First, there are various multicultural themes and characteristics in the 2013 Curriculum Textbook of Religion and Ethics Education. Second, dialectics and the way the Catholic Church organizes the preaching of multicultural values in the 2013 Curriculum Religion and Ethics Textbook. This study can contribute to developing the concept and policies regarding the teaching of multiculturalism in Indonesia, a pluralist country, to become a model for similar countries.
\end{abstract}

Keywords: Catholicism; evangelism; moral lessons; multiculturalism; religious textbooks.

Abstrak: Kajian ini mendiskusikan muatan nilai multikultural dalam Buku Ajar Pendidikan Agama Katolik dan Etika Kurikulum 2013, sehingga dapat mendeskripsikan dan menganalisis berbagai tema dan karakteristik nilai multikultural dalam Buku Ajar tersebut. Selain itu, penelitian ini juga bertujuan untuk mendeskripsikan dan menganalisis dialektika dan cara Gereja Katolik melakukan evangelisasi nilai-nilai multikultural dalam buku teks yang dibahas. Pendidikan agama yang meliputi ciri-ciri dan tingkatan nilai multikultural yang secara resmi mengungkapkan Gereja mewartakan nilai-nilai multikultural. Kajian ini bersifat penelitian literatur dengan menggunakan metode analisis isi dan pendekatan analisis konseptual terhadap buku ajar yang dibahas. Hasil penelitian menunjukkan adanya muatan nilai multikultural di dalamnya. Berdasarkan analisis tersebut, penelitian ini memiliki dua kesimpulan yang merangkum pencapaian tujuannya. Pertama, adanya berbagai tema dan karakteristik multikultural dalam Buku Ajar Pendidikan Agama dan Etika Kurikulum 2013. Kedua, adanya dialektika dan cara Gereja Katolik menyelenggarakan dakwah nilai-nilai multikultural dalam Buku Ajar Pendidikan Agama dan Etika Kurikulum 2013. Kajian ini dapat memberikan kontribusi pada pengembangan konsep dan kebijakan tentang pengajaran multikulturalisme di Indonesia yang merupakan negara yang pluralis, sehingga dapat menjadi model bagi negara-negara serupa.

Kata Kunci: Agama Katolik; buku teks keagamaan; evangelisasi; multikulturalisme; pelajaran moral.

\section{Pendahuluan}

Setiap agama memerintahkan pemeluknya untuk menyampaikan segala sesuatu yang diketahuinya tentang agamanya kepada orang lain (Arnold, 1981; Sosteric, 2021). Aktivitas ini mendapat sebutan dakwah atau misi (Dunch, 2002; Luthfi, 2019; Mochizuki, 2010; Nurhayati, Junaedi, 
\& Sahliah, 2020). Secara khusus, Gereja Katolik menyebut aktivitas pewartaan atau dakwah sebagai 'evangelisasi' (del Castillo \& Alino, 2020; Dulles, 1992). Aktivitas dakwah atau misi menjadi bagian integral agama, walaupun praktik penyampaiannya memiliki relasi dengan entitas lain (Dein, Loewenthal, Lewis, \& Pargament, 2020; Dermawan, 2002). Pada setiap agama semangat menyebarkan ajaran agama kepada orang lain merupakan bagian dari kewajiban. Adanya perintah dalam kitab suci masing-masing untuk menjalankan kewajiban tersebut membuat aktivitas dakwah atau misi itu menjadi motivasi bagi para penganutnya (Dister, 1994; Mehfooz, 2021).

Akan tetapi, motivasi para penganut agama melaksanakan aktivitas dakwah atau misi sebenarnya tidak hanya atas dasar perintah agama. Menurut Max Weber, para penganut agama dapat melaksanakan aktivitas dakwah atau misi atas dasar rasionalitas. Menurut Weber, terdapat dua jenis rasionalitas. Pertama, rasionalitas bertujuan. Rasionalitas bertujuan mengarahkan manusia pada tindakan-tindakan yang berorientasi mencapai tujuan sekaligus membantu manusia memahami caracara pencapaian tujuan serta pelbagai konsekuensinya. Kedua, rasionalitas nilai. Rasionalitas nilai mengarahkan manusia untuk berorientasi pada nilai-nilai tertentu dalam kegiatan pencapaian tujuan (Aimonetti \& Talley, 2021; Weber, 1978). Dakwah yang terkandung di dalam Al-Quran atau evangelisasi yang terkandung di dalam Alkitab berperan sebagai legitimasi sekaligus dasar individu penganut agama dalam bertindak. Weber menyebut tindakan semacam itu sebagai tindakan valuerational (Martinez, Peattie, \& Vazquez-Brust, 2021; Oakes, 2003).

Tindakan value-rational berbasiskan teks suci itu dapat membuat aktivitas dakwah atau misi bersifat eksklusif. John Titaley berpendapat eksklusivisme agama menghasilkan sikap diskriminatif dan kompetitif. Akhirnya, terjadilah kekerasan di mana-mana atas nama Tuhan (Titaley, 2009). Saat terjadi tindak kekerasan yang dilakukan agama atas nama Tuhan, aktivitas dakwah atau misi agama justru menjadi ambigu. Pengajaran-pengajaran agama yang bertujuan meningkatkan kehidupan justru disampaikan dengan kekerasan yang ditentangnya (Küster, 2014).

Aktivitas misi disertai tindak kekerasan atas nama agama dan Tuhan pernah menjadi realitas historis Gereja Katolik. Realitas tersebut terjadi saat Katolik menjadi agama yang dominan di Barat (Dawson, 1929). Dari dominasi tersebut muncullah suatu ungkapan 'Kristen Barat' (Koterski, 1993). Dalam perkembangannya, konteks 'Kristen Barat' melahirkan sebuah kalimat penting yang diyakini menjadi ajaran utama Gereja Katolik pada saat itu, terkait pandangannya terhadap agama-agama lain. Kalimat itu adalah 'Extra Ecclesiam Nulla Salus'. Artinya, 'di luar gereja tiada keselamatan'. Adagium ini menjadi salah satu penyebab mengapa selama berabad-abad, pandangan Gereja Katolik tentang keselamatan orang-orang non-Kristen adalah murni eksklusif (Denzinger, 1957). Kalimat ini dituduh menjadi biang keladi berkembangnya eksklusivisme dalam Gereja Katolik (D'Costa, 1990; DiNoia, 1992; Fornberg, 1995).

Kalimat yang bertransformasi menjadi ajaran (doktrin) ini menegaskan bahwa Kristianitas adalah agama yang eksklusif, dominan, dan berderajat lebih tinggi dibandingkan agama-agama lainnya (McGrath, 1997). Oleh karena itu, keselamatan adalah mutlak dimiliki gereja. Siapa pun yang ingin selamat (masuk surga) harus melalui gereja. Artinya, dibaptis menjadi orang Kristen. Ajaran ini sedemikian kuat sehingga hampir semua warga Kekaisaran Romawi dibaptis menjadi Kristen (Katolik) (Clendenin, n.d.). Penolakan terhadap Kristianitas disamakan dengan penolakan terhadap kuasa Kekaisaran. Dengan kata lain, menolak dibaptis berarti memberontak terhadap pemerintahan yang legal. Jika tidak memahami makna asali dan konteksnya, orang dengan mudah dapat menyalahartikan doktrin ini karena sekilas hanya memperjuangkan eksklusivitas Gereja. Dengan kata lain, doktrin ini seakan-akan menutup pintu bagi nilai-nilai multikultural, baik bagi Gereja sendiri maupun yang berasal dari Gereja. Sasaran adagium ini sebenarnya adalah orang-orang murtad dan kaum skismatik (Clarke, 1973).

Gereja Katolik membutuhkan waktu berabad-abad untuk akhirnya sampai pada suatu sikap yang tegas terkait peralihan sikapnya dari eksklusif menjadi inklusif. Sikap inklusif Gereja Katolik baru dinyatakan secara tegas dan resmi pada Konsili Vatikan II (1965) (Knitter, 1985). Teolog Katolik, Karl Rahner (1904-1984) dan Henri de Lubac (1896-1991) dianggap sebagai tokoh yang bertanggung jawab atas sikap inklusif gereja ini. Paul F. Knitter menjelaskan bahwa untuk pertama kalinya Gereja Katolik 
menyampaikan pernyataan resmi tentang sikap inklusifnya terhadap agama-agama lain dalam Dokumen Nostra Ætate (Ruokanen, 1992). Di dalam dokumen tersebut Gereja Katolik antara lain memberi penghargaan kepada setiap agama besar yang ada di dunia ini dan penghargaan atas inisiatif agama-agama tersebut untuk mendalami dan memaknai misteri kehidupan manusia (Knitter, 1985). Singkatnya, Konsili Vatikan II mentransformasi orientasi dakwah atau misi Gereja Katolik dari eksklusif menjadi inklusif dalam wujud ajaran bermuatan pluralis-multikultural.

Henri de Lubac secara khusus menyoroti transformasi pewartaan nilai-nilai pluralismemultikultural Gereja Katolik pasca-Konsili Vatikan II. Henri de Lubac menggunakan adagium milik Thomas Aquinas, desiderium naturale vivendi Deum (hasrat alamiah untuk bertekuk lutut di hadapan Tuhan) sebagai dasarnya (Cai, 2014). Menurut de Lubac, setiap manusia dari agama atau keyakinan apa pun memiliki hasrat alamiah untuk bertekuk lutut di hadapan Tuhan. Hasrat alamiah ini berlaku universal (Lubac, 1967). Dengan kata lain, semua manusia memiliki kerinduan kodrati terhadap yang adikodrati. Bagi umat Katolik, kerinduan itu terjawab dalam sosok Yesus Kristus sebagai anugerah yang sempurna (donum perfectum). Kehadiran Yesus Kristus yang membawa keselamatan ini tidak berlaku hanya bagi umat Kristiani. Keselamatan itu berlaku secara universal. Artinya, keselamatan itu berlaku bagi semua orang dari agama dan keyakinan apa pun tanpa kecuali. Konsekuensi gagasan ini adalah bahwa tidak ada seorang manusia pun yang berhak menghakimi sesamanya tidak selamat karena Tuhan menghendaki keselamatan bagi seluruh umat manusia.

Sejak Konsili Vatikan II Gereja Katolik gencar menyebarkan gagasan-gagasan pluralismultikultural yang terdapat dalam ajaran-ajarannya. Untuk itu, Gereja Katolik menggunakan aneka macam cara. Salah satu wujud aktual gagasan-gagasan inklusivisme dan pluralisme dalam Gereja Katolik adalah menyelenggarakan pendidikan multikultural. Secara umum pendidikan multikultural dapat diselenggarakan melalui sejumlah mata pelajaran di sekolah, terutama mata pelajaran PKN dan IPS, bahasa dan sebagainya (Wihardit, 2010). Setiap guru mata pelajaran dapat mengintegrasikan pendidikan multikultural dalam mata pelajaran yang diampunya (Rohman \& Mukhibat, 2017). Walaupun demikian, di Indonesia Pendidikan Agama dianggap paling memungkinkan untuk memuat pendidikan multikultural (Abdullah, 2005). Pendidikan agama dapat menekankan bahwa multikulturalisme merupakan suatu kesempatan dan kemungkinan untuk saling belajar tentang mempersiapkan dan merayakan pluralitas agama - dan etnik serta kultural - melalui dunia pendidikan (Baidhawy, 2005).

Di Indonesia pendidikan agama untuk siswa beriman Katolik disampaikan melalui Pelajaran Agama Katolik dan Budi Pekerti (PAK). PAK ini berlaku semua tingkatan dan kelas yang diselenggarakan di sekolah-sekolah Katolik maupun non-Katolik. Penelitian ini memilih PAK sebagai subjek penelitiannya atas dasar dua alasan. Pertama, sebagai lembaga, salah satu ujung tombak pelayanan Gereja Katolik terhadap umat (jemaat) dan masyarakat adalah sekolah. Sepanjang sejarah, Gereja Katolik memposisikan sekolah sebagai wadah untuk menyampaikan ajaran-ajaran pokoknya, termasuk ajaran tentang nilai-nilai multikultural. Kedua, di sekolah-sekolah tersebut, PAK menjadi ranah yang paling memungkinkan untuk menyelenggarakan wawasan multikulturalisme (Abdullah, 2005).

Secara lebih spesifik penelitian ini menempatkan buku teks Pendidikan Agama Katolik dan Budi Pekerti (PAK) Kurikulum 2013 sebagai objek penelitian (Mansur, 2010). Terkait dengan muatan nilainilai multikultural yang akan dianalisis dari objek penelitian tersebut, G. M. Ameny-Dixon (AmenyDixon, 2004) membentangkan posisi buku teks dalam bingkai konsep gagasan global tentang nilai-nilai multikultural untuk membantu proses penelitian tentang nilai-nilai multikultural yang terdapat di dalam PAK Kurikulum 2013. Alasannya, buku teks ini menjadi dasar semua materi ajar dalam PAK. Oleh karena itu, penelitian ini memiliki dua tujuan. Pertama, mendeskripsikan dan menganalisis ragam tema dan karakteristik nilai-nilai multikultural dalam buku teks Pendidikan Agama dan Budi Pekerti (PAK) Kurikulum 2013. Kedua, mendeskripsikan dan menganalisis dialektika dan cara Gereja Katolik menyelenggarakan pewartaan tentang nilai-nilai multikultural dalam buku teks Pendidikan Agama Katolik dan Budi Pekerti (PAK) Kurikulum 2013. 
Kajian seperti ini sudah banyak dilakukan di Indonesia, mengingat begitu pentingnya nilai-nilai multikulturalisme diajarkan di sekolah-sekolah. Demikian karena pluralisme itu sendiri memang menjadi semacam condition sine qua non di Indonesia (Rahman, 2010). Kajian-kajian tersebut memang masih banyak yang secara khusus membahas nilai-nilai multikulturalisme di buku-buku pelajaran Pendidikan Agama Islam (PAI) (Khozin, 2019; Luwihta, 2016; Mumtahanah, 2019; Muzayanah, 2017; Pradana, 2017). Ada juga yang sudah memperbandingkan antara buku teks Islam dan Kristen (Murfi, 2016). Namun yang secara khusus membahas nilai-nilai multikulturalisme pada buku teks Pendidikan Agama Katolik (PAK) sejauh ini belum terekspos. Dengan demikian, kajian ini menjadi relatif baru dan niscaya untuk dilakukan guna mengevaluasi sejauh mana nilai-nilai multikulturalisme diadopsi pada PAK.

\section{Ragam tema dan karakteristik nilai-nilai multikultural buku teks PAK Kurikulum 2013}

Sebagaimana pelajaran lainnya Pendidikan Agama Katolik dan Budi Pekerti (PAK) Kurikulum 2013 menggunakan buku teks sebagai sarana utama penyampaian materi ajarnya. Secara umum, buku teks PAK Kurikulum 2013 Kelas I sampai dengan Kelas XII memuat kata pengantar dari Komisi Kateketik Konferensi Waligereja Indonesia (Komkat KWI). Kata pengantar itu menegaskan bahwa buku teks ini disusun berdasarkan Kurikulum 2013. Secara khusus disebutkan pula bahwa pembelajaran agama diharapkan mampu menambah wawasan keagamaan, mengasah keterampilan beragama dan mewujudkan sikap beragama peserta didik yang utuh dan berimbang yang mencakup hubungan manusia dengan Penciptanya, sesama manusia dan manusia dengan lingkungannya. Untuk itu, pendidikan agama perlu diberi penekanan khusus terkait dengan penanaman karakter dalam pembentukan budi pekerti yang luhur. Karakter yang ingin ditanamkan adalah kejujuran, kedisiplinan, cinta kebersihan, cinta kasih, semangat berbagi, optimisme, cinta tanah air, kepenasaran intelektual, dan kreativitas (Komisi Kateketik, 2017).

Selaras dengan tuntutan Kurikulum 2013, PAK memuat dua kategori kompetensi, yaitu Kompetensi Inti dan Kompetensi Dasar. Kompetensi Inti adalah pengikat pelbagai Kompetensi Dasar yang harus dihasilkan dengan mempelajari tiap mata pelajaran. Melalui Kompetensi Inti, integrasi vertikal pelbagai Kompetensi Dasar pada kelas yang berbeda dapat dijaga. Sedangkan Kompetensi Dasar adalah kompetensi setiap mata pelajaran untuk setiap kelas yang diturunkan dari Kompetensi Inti. Kompetensi Dasar merupakan konten atau kompetensi yang terdiri atas sikap, pengetahuan, dan keterampilan (kognitif dan psikomotorik) yang bersumber pada Kompetensi Inti yang harus dikuasai peserta didik. Kompetensi tersebut dikembangkan dengan memperhatikan karakteristik peserta didik, kemampuan awal, serta ciri dari suatu mata pelajaran, mengingat standar kompetensi lulusan harus dicapai pada setiap akhir jenjang Pendidikan (Kementerian Pendidikan dan Kebudayaan, 2015).

Secara akumulatif, PAK Kurikulum 2013 menunjukkan adanya total 400 Kompetensi Dasar dari kelas I (SD) sampai dengan kelas XII (SMA). Total 400 Kompetensi Dasar itu mengalami proses analisis untuk menemukan dan mendeskripsikan prosentase muatan nilai-nilai multikulturalnya. Indikator yang digunakan adalah empat nilai inti (core values) multikultural menurut C. Bennett dan Dody S. Truna. Menurut Dody S. Truna dengan merujuk pada penelitian C. Bennett, semua wujud pendidikan multikultural itu harus senantiasa memuat empat nilai intinya. Pertama, apresiasi terhadap keragaman budaya yang terdapat dalam kehidupan masyarakat. Kedua, pengakuan terhadap kesamaan harkat, martabat, dan hak asasi manusia. Ketiga, penanaman rasa tanggung jawab manusia terhadap keragaman budaya pada masyarakat dunia. Keempat, pengembangan tanggung jawab manusia terhadap planet bumi (Bennett, 1986; Truna, 2017).

Proses analisis seperti disajikan pada gambar 1, menemukan bahwa terdapat 159 Kompetensi Dasar atau 39,7\% dari total jumlah Kompetensi Dasar PAK yang mengandung atau memuat nilai-nilai multikultural dengan sebaran prosentase yang berbeda-beda di tiap kelasnya. Diagram lingkaran (pie chart) berikut ini menunjukkan bahwa buku teks PAK Kelas I SD sampai dengan Kelas XI SMA memuat 39,7\% Kompetensi Dasar yang bermuatan nilai-nilai multikultural. 


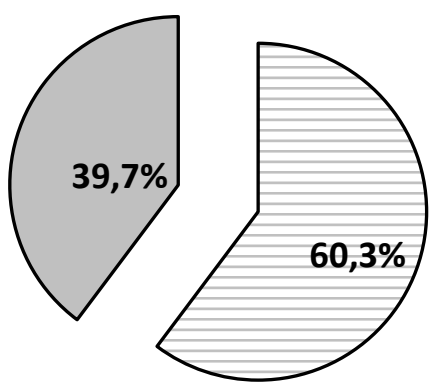

$$
\begin{aligned}
& \text { 口eksklusif } \\
& \square \text { inklusif }
\end{aligned}
$$

Sementara itu secara visual, grafik berikut ini menunjukkan tinggi-rendah muatan nilai-nilai multikultural yang terdapat pada Kompetensi Dasar dari masing-masing buku teks dari Kelas I SD sampai dengan Kelas XII.

Gambar 2. Tinggi-Rendah Nilai-nilai Multikultural dalam PAK Kelas I SD-Kelas IX SMA

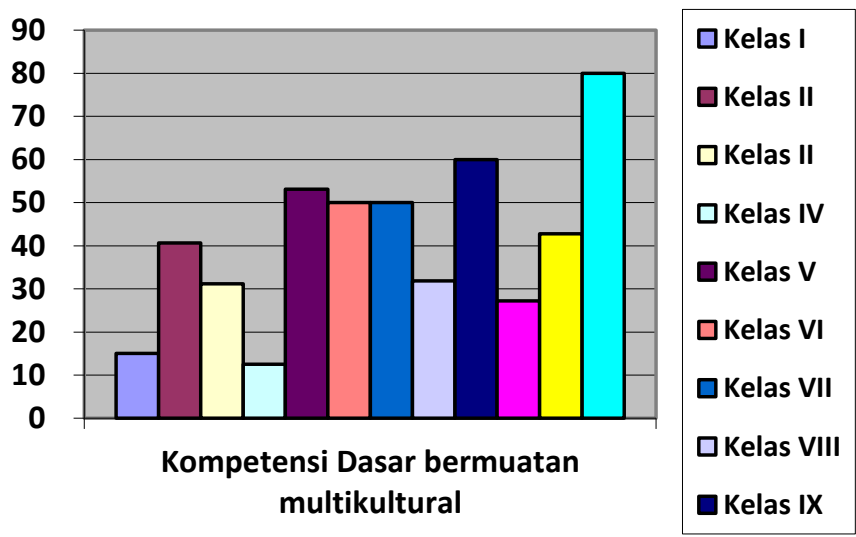

Berdasarkan grafik pada gambar 2, buku teks PAK Kelas I sampai dengan Kelas VI SD memuat 33,8\% Kompetensi Dasar yang bermuatan nilai-nilai multikultural. Sementara itu grafik juga menunjukkan bahwa buku teks PAK Kelas VII sampai dengan Kelas IX SMP mengandung 46,5\% Kompetensi Dasar yang bermuatan nilai-nilai multikultural. Sedangkan grafik menunjukkan bahwa buku teks PAK Kelas X sampai dengan Kelas XII SMA memuat 43,3\% Kompetensi Dasar yang bermuatan nilai-nilai multikultural.

Jika dilihat secara berjenjang, buku teks PAK SMP yang paling banyak mengandung Kompetensi Dasar yang bermuatan nilai-nilai multikultural, yaitu 46,5\%. Sedangkan buku teks PAK SD mengandung paling sedikit Kompetensi Dasar yang bermuatan nilai-nilai multikultural, yaitu 33,8\%. Sedangkan jika dilihat dari muatan per-kelas, buku teks PAK kelas XII SMA merupakan yang paling banyak mengandung Kompetensi Dasar yang bermuatan nilai-nilai multikultural, yaitu $80 \%$. Sedangkan yang terkecil adalah buku teks PAK kelas IV SD, yaitu 12,5\%. Berdasarkan data tersebut menjadi jelas bahwa kompetensi berbasiskan nilai-nilai multikultural yang harus dimiliki setiap siswa sejak SD sampai dengan SMA sekurang-kurangnya 33,8\% secara umum.

Pada buku teks Kompetensi Dasar dituangkan dalam tema-tema. Penggunaan tema-tema pembelajaran sebagai pokok bahasan dapat mengintegrasikan beberapa Kompetensi Dasar sekaligus. Integrasi yang dilakukan mencakup dua hal. Pertama, integrasi sikap, keterampilan, dan pengetahuan dalam pembelajaran. Kedua, integrasi berbagai konsep dasar yang berkaitan (Daryanto, 2014). Dengan mengutip Pedoman Pembelajaran Tematik yang diterbitkan Pusat Kurikulum Balitbang Depdiknas 
(2006), Mujimin menjelaskan bahwa tema-tema pembelajaran akan memberikan banyak keuntungan dalam praktik pembelajaran (Mujimin, 2006).

Berdasarkan pendapat Mujimin (2006) tersebut, pembahasan menggunakan tema-tema yang terdapat pada buku teks PAK Kurikulum 2013 menjadi jalan bagi siswa untuk mencapai Kompetensi Dasar bermuatan nilai-nilai multikultural yang dideskripsikan pada bagian sebelumnya dengan nilainilai multikultural (core values) sebagai indikatornya. Berikut ini sebaran tema-tema multikultural yang terdapat dalam PAK.

Tabel 1. Sebaran Tema-tema Multikultural dalam PAK

\begin{tabular}{|c|c|c|}
\hline \multicolumn{2}{|r|}{ Aspek Multikultural } & \multirow[b]{2}{*}{ Kelas } \\
\hline $\begin{array}{c}\text { Nilai-nilai } \\
\text { Multikultural }\end{array}$ & Tema-tema Multikultural & \\
\hline \multirow{3}{*}{$\begin{array}{l}\text { Apresiasi } \\
\text { terhadap } \\
\text { keragaman } \\
\text { budaya. }\end{array}$} & $\begin{array}{l}\text { Keberagaman sebagai realitas asali kehidupan } \\
\text { manusia }\end{array}$ & III, VI, IX, XII \\
\hline & Kekhasan agama-agama di Indonesia & IX, XII \\
\hline & Dialog antarumat beragama dan kepercayaan lain & XII \\
\hline \multirow{4}{*}{$\begin{array}{l}\text { Pengakuan } \\
\text { terhadap } \\
\text { kesamaan harkat, } \\
\text { martabat, dan } \\
\text { Hak Asasi } \\
\text { Manusia. }\end{array}$} & $\begin{array}{l}\text { Hak Asasi Manusia dalam terang Kitab Suci dan } \\
\text { Ajaran Gereja }\end{array}$ & V, IX, XI \\
\hline & Aborsi & $\mathrm{XI}$ \\
\hline & Hukuman mati & $\mathrm{XI}$ \\
\hline & Kesetaraan laki-laki dan perempuan & I, IV, V, VII, X \\
\hline \multirow{8}{*}{$\begin{array}{l}\text { 3. Penanaman rasa } \\
\text { tanggung jawab } \\
\text { terhadap } \\
\text { keragaman } \\
\text { budaya pada } \\
\text { masyarakat } \\
\text { dunia. }\end{array}$} & Keadilan & V, VI, XII \\
\hline & Kebenaran & XII \\
\hline & Kejujuran & V, VI, XII \\
\hline & Hak dan kewajiban sebagai warga negara & VI, VII \\
\hline & $\begin{array}{l}\text { Membangun persaudaraan sejati melalui kerja sama } \\
\text { antarumat beragama dan berkepercayaan lain }\end{array}$ & VII, VIII, IX, XII \\
\hline & Mengupayakan perdamaian dan persatuan bangsa & II, IV, XI, XII \\
\hline & $\begin{array}{l}\text { Bersikap kritis terhadap ideologi dan gaya hidup } \\
\text { yang berkembang dewasa ini }\end{array}$ & III, $\mathrm{X}$ \\
\hline & Gereja sebagai persekutuan yang terbuka & IV, VII, IX, XI \\
\hline \multirow{3}{*}{$\begin{array}{l}\text { 4. Pengembangan } \\
\text { tanggung jawab } \\
\text { manusia } \\
\text { terhadap planet } \\
\text { bumi. }\end{array}$} & Keutuhan lingkungan hidup ciptaan Tuhan & I, III, V, IX, XII \\
\hline & Permasalahan yang dihadapi dunia & $\mathrm{VI}, \mathrm{XI}$ \\
\hline & Ajaran Sosial Gereja & XI \\
\hline
\end{tabular}

Berdasarkan data sebaran dalam tabel 1, di dalam buku teks PAK Kurikulum 2013 terdapat 48 bagian buku teks yang memuat nilai-nilai multikultural. Nilai-nilai tersebut memenuhi indikatornya, yaitu empat nilai inti (core values) multikultural menurut C. Bennett. Dari keempat nilai inti multikultural itu, nilai inti multikultural yang memiliki ragam tema paling bervariasi adalah penanaman rasa tanggung jawab terhadap keragaman budaya pada masyarakat dunia dengan jumlah delapan tema. Sedangkan berdasarkan tema-tema materi ajar, Tabel 1 menunjukkan bahwa tema 'kesetaraan laki-laki dan perempuan' dan tema 'keutuhan lingkungan hidup ciptaan Tuhan' paling banyak muncul. Tema 'kesetaraan laki-laki dan perempuan' menjadi pokok pembahasan di Kelas I, 
Kelas IV, Kelas V, Kelas VII, dan Kelas X. Sedangkan tema 'keutuhan lingkungan hidup ciptaan Tuhan' menjadi pokok pembahasan di Kelas I, Kelas III, Kelas V, Kelas IX, dan Kelas XII.

Setelah kedua tema tersebut menyusul empat tema lain yang muncul menjadi pokok pembahasan. Pertama, keberagaman sebagai realitas asali kehidupan manusia. Tema itu menjadi pokok pembahasan di Kelas III, Kelas VI, Kelas IX, dan Kelas XII. Kedua, membangun persaudaraan sejati melalui kerja sama antarumat beragama dan berkepercayaan lain. Tema itu menjadi pokok pembahasan di Kelas VII, Kelas VIII, Kelas IX, Kelas XII. Ketiga, mengupayakan perdamaian dan persatuan bangsa. Tema ini menjadi pokok pembahasan di Kelas II, Kelas IV, Kelas XI, dan Kelas XII. Keempat, Gereja sebagai persekutuan yang terbuka. Tema ini menjadi pokok pembahasan di Kelas IV, Kelas VII, Kelas IX, dan Kelas XI.

Tiga tema berikutnya menempati urutan ketiga terbanyak muncul. Pertama, keadilan. Tema ini menjadi pokok pembahasan di Kelas V, Kelas VI, dan Kelas XII. Kedua, kejujuran. Tema ini menjadi pokok pembahasan di Kelas V, Kelas VI, dan Kelas XII. Sebagai catatan, di Kelas V dan Kelas VI kedua tema ini menjadi satu pokok bahasan. Ketiga, Hak Asasi Manusia dalam terang Kitab Suci dan Ajaran Gereja. Tema ini menjadi pokok pembahasan di Kelas V, Kelas IX, dan Kelas XI.

Urutan berikutnya menjadi posisi empat tema lainnya. Pertama, kekhasan agama-agama di Indonesia. Tema itu menjadi pokok pembahasan di Kelas IX dan Kelas XII. Kedua, hak dan kewajiban sebagai warga negara. Tema itu menjadi pokok pembahasan di Kelas VI dan Kelas VII. Ketiga, bersikap kritis terhadap ideologi dan gaya hidup yang berkembang dewasa ini. Tema itu menjadi pokok pembahasan di Kelas III dan Kelas X. Keempat, permasalahan yang dihadapi dunia. Tema itu menjadi pokok pembahasan di Kelas VI dan Kelas XI.

Buku teks PAK Kurikulum 2013 juga memuat lima tema yang muncul satu kali sebagai satu pokok pembahasan dalam satu kelas tersendiri. Pertama, dialog antarumat beragama dan kepercayaan lain di Kelas XII. Kedua, Aborsi di Kelas XI. Ketiga, hukuman mati di Kelas XI. Keempat, kebenaran di Kelas XII. Kelima, Ajaran Sosial Gereja (ASG) di Kelas XII. Variasi sekaligus muatan tema-tema multikultural pada buku teks PAK untuk Kelas XII adalah yang terbanyak dengan jumlah sembilan tema. Data ini selaras atau berbanding lurus dengan data pada grafik Kompetensi Dasar yang menunjukkan bahwa buku teks PAK untuk Kelas XII adalah yang paling banyak memuat Kompetensi Dasar yang bermuatan nilai-nilai multikultural dengan jumlah $80 \%$ dari total pokok pembahasannya.

Pembahasan dan analisis terhadap buku teks Pendidikan Agama Katolik (PAK) Kurikulum 2013 mengidentifikasi adanya muatan nilai-nilai multikultural di dalamnya. Muatan nilai-nilai multikultural itu muncul dalam enam belas (16) ragam tema. Keenambelas ragam tema itu adalah sebagai berikut.

(1) Keberagaman sebagai realitas asali kehidupan manusia

(2) Kekhasan agama-agama di Indonesia

(3) Dialog antarumat beragama dan kepercayaan lain

(4) Hak Asasi Manusia dalam terang Kitab Suci dan Ajaran Gereja

(5) Aborsi

(6) Hukuman mati

(7) Kesetaraan laki-laki dan perempuan

(8) Keadilan, kebenaran, dan kejujuran

(9) Hak dan kewajiban sebagai warga negara

(10) Membangun persaudaraan sejati melalui kerja sama antarumat beragama dan berkepercayaan lain

(11) Mengupayakan perdamaian dan persatuan bangsa

(12) Bersikap kritis terhadap ideologi dan gaya hidup yang berkembang dewasa ini

(13) Gereja sebagai persekutuan yang terbuka

(14) Keutuhan lingkungan hidup ciptaan Tuhan

(15) Permasalahan yang dihadapi dunia

(16) Ajaran Sosial Gereja (ASG) 
Buku teks PAK membahas masing-masing tema tersebut dengan menggunakan sejumlah ilustrasi kondisi kontekstual sekaligus memberi basis pendasaran dari teks-teks Kitab Suci dan Ajaran Gereja (Magisterium). Untuk menjamin keselarasan nilai-nilai multikultural yang termuat dalam buku teks PAK Kurikulum 2013 dengan pewartaan Gereja sangat mendesak (urgen) upaya analisis secara terusmenerus. Upaya analisis ini dapat dilaksanakan dengan memerhatikan aspek kuantitatif dan aspek kualitatif muatan nilai-nilai multikultural yang terdapat dalam buku teks PAK Kurikulum 2013. Dari aspek kuantitatif, terlihat bahwa prosentase muatan nilai-nilai multikultural dalam buku teks PAK Kurikulum 2013 cukup, yaitu 39,7\%. Akan tetapi, sebaran muatannya belum seimbang.

Terjadi kesenjangan yang tajam antara prosentase muatan nilai-nilai multikultural pada buku teks PAK Kelas IV SD (12,5\%) dengan muatan nilai-nilai multikultural pada buku teks Kelas XII SMA (80\%). Prosentase muatan nilai-nilai multikultural yang lebih besar pada buku teks PAK untuk SMA dinilai sudah tepat, mengingat siswa SMA berada pada usia rentan dan belum stabil sehingga mudah menerima provokasi dan pengaruh dari luar (Qodir, 2013). Hal ini senada dengan pendapat James W. Fowler (Muzayanah, 2017). Menurut Fowler, siswa SMA berada pada tahap sintetik konvensional, yaitu tahapan di mana siswa akan patuh terhadap pendapat dan kepercayaan orang lain. Pada tahap ini pula siswa dapat dengan mudah menerima doktrin dari luar, termasuk doktrin yang bertentangan dengan nilai-nilai agama yang dianutnya (Umro, 2018).

Supaya berimbang dengan tingkatan lainnya, muatan nilai-nilai multikultural pada buku teks PAK tingkat SD juga harus ditingkatkan, terutama untuk memberikan informasi tentang adanya keberagaman di Indonesia. Menurut Jean Piaget (Piaget, 1968), perkembangan anak pada usia Sekolah Dasar (6-12 tahun) ditandai dengan penggunaan logika yang memadai. Pada tahap ini anak memiliki kemampuan untuk mengklasifikasi sesuatu berdasarkan karakteristik tertentu. Ia dapat mengklasifikasi sekelompok objek. Misalnya, kelereng berdasarkan warna dan ukurannya. Dengan demikian, ia pun dapat membedakan teman-temannya berdasarkan warna kulit, tinggi, bentuk rambut, sampai suku atau agama temannya. Proses-proses penting selama tahapan ini adalah mengenal bentuk, ukuran, ciri-ciri dan lain sebagainya. Selain itu, anak-anak dapat memahami hukumhukum percakapan dan mampu mengklasifikasikan dan mengurutkan sesuatu dari besar ke kecil dan juga sebaliknya (Woolfolk, 2016). Dengan informasi itu, anak dapat mengenal 'keberagaman' secara sederhana seperti beragamnya jenis kelereng berdasarkan klasifikasi yang dibuatnya (Hardianto, 2014).

Secara kualitatif, meskipun sudah diberikan di dalam pembelajaran agama, ada bahaya bahwa konsep-konsep multikultural hanya berhenti pada pengetahuan (Wijaya \& Gaudiawan, 2020). Hal ini terjadi akibat metode yang dipilih umumnya menekankan aspek kognitif yang dalam hal tertentu melupakan aspek afektif dan operatif dari suatu pendidikan iman yang sebenarnya dapat memengaruhi perubahan sikap. Ini mengakibatkan pemahaman para siswa untuk sampai pada aplikasi sikap cenderung lemah. Padahal, menurut M. Ainul Yaqin, pendidikan multikultural harus sampai pada tahap melatih dan membangun karakter siswa supaya mampu bersikap demokratis, humanis, dan pluralis dalam lingkungan mereka (Yaqin, 2021).

Oleh karena itu, guna semakin mengoptimalkan pembelajaran multikulturalisme yang ada, perlu diciptakan strategi atau metode pembelajaran berdimensi operasional yang memungkinkan terjadinya dialog sehingga para siswa dapat saling mengenal ajaran agama masing-masing (Wijaya \& Gaudiawan, 2020). Misalnya, kunjungan dan dialog langsung dengan para pemuka agama. Strategi atau metode pembelajaran berdimensi operasional semacam ini memberi pengalaman langsung kepada siswa. Pengalaman langsung memiliki pengaruh afektif yang tidak dapat diberikan informasi yang diberikan secara kognitif. Dialog bukan hanya meningkatkan akan pentingnya rasa dan sikap toleransi, melainkan juga pengalaman transformatif bagi pihak-pihak yang terlibat (Harjuna, 2019). Menurut Hans Küng, dialog dalam wujud pengalaman langsung jauh lebih penting dari presisi akademik dan teologi. Dialog harus melampaui ajaran teoretis atau teologis (Kung, 1986).

Secara kualitatif diperlukan adanya pendalaman terhadap konteks dan refleksi atas basis ajaran yang digunakan. Dengan kata lain, Pendidikan Agama dalam penyelenggaraannya harus mampu menjaga dan menyeimbangkan antara sejarah dan konteksnya, reflektivitas, serta tradisi dan 
pencerahan (Meijer, 2010). Untuk itu, rujukan dokumen harus senantiasa menggunakan yang terkini. Misalnya, Dokumen Perjalanan Apostolik Bapa Suci Paus Fransiskus ke Uni Emirat Arab (UEA), 3-5 Februari 2019 tentang Persaudaraan Manusia untuk Perdamaian Dunia dan Hidup Beragama (KWI, 2019) dan Nota Pastoral Konferensi Waligereja Indonesia 2018 tentang Panggilan Gereja dalam Hidup Berbangsa. Menjadi Gereja yang Relevan dan Signifikan (KWI, 2018). Seiring dengan itu ilustrasi yang dipakai juga harus senantiasa aktual dan relevan karena dinamika multikulturalitas, terutama di Indonesia terus berkembang.

Secara ringkas, analisis atas ragam tema multikultural pada buku teks PAK Kurikulum 2013 dapat dijelaskan dalam tabel 2.

Tabel 2. Analisis atas Ragam Tema Multikultural pada Buku Teks PAK Kurikulum 2013

\begin{tabular}{lll}
\hline \multicolumn{1}{c}{ Kecenderungan } & \multicolumn{1}{c}{ Indikator } & \multicolumn{1}{c}{ Tawaran Gagasan } \\
\hline $\begin{array}{l}\text { Dari aspek kuantitatif } \\
\text { prosentase muatan nilai- } \\
\text { nilai multikultural dalam } \\
\text { buku teks PAK Kurikulum } \\
2013 \text { cukup. }\end{array}$ & $\begin{array}{l}\text { Ada 39,7\% muatan nilai- } \\
\text { nilai multikultural dalam } \\
\text { buku teks PAK Kurikulum } \\
2013 \text { yang berwujud aneka } \\
\text { tema. }\end{array}$ & $\begin{array}{l}\text { Sebaran muatannya belum } \\
\text { seimbang. Muatan nilai-nilai } \\
\text { multikultural pada buku teks PAK } \\
\text { tingkat SD harus ditingkatkan, } \\
\text { terutama untuk memberikan } \\
\text { informasi tentang adanya } \\
\text { keberagaman di Indonesia. }\end{array}$ \\
\hline $\begin{array}{l}\text { Secara kualitatif, meskipun } \\
\text { sudah diberikan di dalam } \\
\text { pembelajaran agama, ada } \\
\text { bahaya bahwa konsep- } \\
\text { konsep multikultural hanya } \\
\text { berhenti pada pengetahuan. }\end{array}$ & $\begin{array}{l}\text { Metode yang dipilih } \\
\text { amumnya menekankan } \\
\text { aspek kognitif yang dalam } \\
\text { aspertentu melupakan }\end{array}$ & $\begin{array}{l}\text { Perlu diciptakan strategi atau } \\
\text { metode pembelajaran berdimensi } \\
\text { operasional yang memungkinkan } \\
\text { terjadinya dialog sehingga para } \\
\text { siswa dapat saling mengenal } \\
\text { ajaran agama masing-masing }\end{array}$ \\
\hline & & $\begin{array}{l}\text { Pendidikan Agama dalam } \\
\text { secara langsung. }\end{array}$ \\
$\begin{array}{l}\text { Secara kualitas, kedalaman } \\
\text { pembahasan belum }\end{array}$ & $\begin{array}{l}\text { Rujukan yang digunakan } \\
\text { bukan yang terkini. }\end{array}$ & $\begin{array}{l}\text { mampu menjaga dan } \\
\text { menyeimbangkan antara sejarah } \\
\text { dan konteksnya, reflektivitas, serta } \\
\text { tradisi dan pencerahan. }\end{array}$ \\
\hline
\end{tabular}

\section{Dialektika pewartaan nilai-nilai multikultural Gereja dalam buku teks PAK Kurikulum 2013}

Deskripsi dan analisis sebaran tema-tema yang bermuatan nilai-nilai multikultural dalam buku teks PAK Kurikulum 2013 menunjukkan dinamika pewartaan Gereja Katolik tentang nilai-nilai multikultural. Dinamika itu nampak dari digunakannya dokumen-dokumen Konsili Vatikan II, terutama dokumen-dokumen yang memiliki orientasi pewartaan ad extra atau inklusif. Dokumendokumen yang dimaksud adalah Nostra Ætate, Gaudium et Spes, Unitatis Redintegratio, dan Ad Gentes. Dengan kata lain, muatan nilai-nilai multikultural dalam buku teks PAK Kurikulum 2013 selaras dengan dinamika pewartaan Gereja tentang nilai-nilai multikultural. Selain dokumen-dokumen tersebut buku teks PAK Kurikulum 2013 melengkapi sumber ajarannya dengan teks-teks Kitab Suci sebagai basis alkitabiah, Kitab Hukum Kanonik sebagai basis hukum, Katekese Gereja Katolik (KGK) sebagai basis katekese, dan sejumlah dokumen yang merupakan wujud konkretisasinya seiring perkembangan zaman, terutama dokumen-dokumen Ajaran Sosial Gereja (ASG). Tabel berikut ini menunjukkan dinamika pewartaan Gereja Katolik tentang nilai-nilai multikultural yang terdapat dalam buku teks PAK Kurikulum 2013 seturut nilai-nilai inti (core values) multikultural berikut sebaran temanya. 
Tabel 3. Nilai-nilai Multikultural yang Terdapat dalam Buku Teks PAK Kurikulum 2013

\begin{tabular}{|c|c|c|}
\hline \multicolumn{2}{|c|}{ Aspek Multikultural } & \multirow[b]{2}{*}{ Sumber Ajaran } \\
\hline $\begin{array}{c}\text { Nilai-nilai } \\
\text { Multikultural } \\
\end{array}$ & Tema-tema Multikultural & \\
\hline \multirow{3}{*}{$\begin{array}{l}\text { 1. Apresiasi } \\
\text { terhadap } \\
\text { keragaman } \\
\text { budaya. }\end{array}$} & $\begin{array}{l}\text { Keberagaman sebagai } \\
\text { realitas asali kehidupan } \\
\text { manusia }\end{array}$ & $\begin{array}{l}\text { 1. Yohanes (Yoh.4:1-42) } \\
\text { 2. Dokumen Konsili Vatikan II, Gaudium et Spes } \\
\text { (Kegembiraan dan Harapan) artikel } 24\end{array}$ \\
\hline & $\begin{array}{l}\text { Kekhasan agama-agama di } \\
\text { Indonesia }\end{array}$ & $\begin{array}{l}\text { 1. Surat Pertama Yohanes (1Yoh.4:21) } \\
\text { 2. Dokumen Konsili Vatikan II, Unitatis Redintegratio } \\
\text { (Dekrit tentang Ekumene) } \\
\text { 3. Dokumen Konsili Vatikan II, Nostra Ætate } \\
\text { (Pernyataan tentang Hubungan Gereja dengan } \\
\text { Agama-agama Bukan Kristen) artikel } 2 \\
\end{array}$ \\
\hline & $\begin{array}{l}\text { Dialog antarumat beragama } \\
\text { dan kepercayaan lain }\end{array}$ & $\begin{array}{ll}\text { 1. Yohanes (Yoh.14:6) } \\
\text { 2. Dokumen Konsili Vatikan II, Nostra Ætate } \\
\text { (Pernyataan tentang Hubungan Gereja dengan } \\
\text { Agama-agama Bukan Kristen) artikel } 2\end{array}$ \\
\hline \multirow{4}{*}{$\begin{array}{l}\text { Pengakuan } \\
\text { terhadap } \\
\text { kesamaan } \\
\text { harkat, } \\
\text { martabat, dan } \\
\text { Hak Asasi } \\
\text { Manusia. }\end{array}$} & $\begin{array}{l}\text { Hak Asasi Manusia dalam } \\
\text { terang Kitab Suci dan Ajaran } \\
\text { Gereja }\end{array}$ & $\begin{array}{ll}\text { 1. } & \text { Kejadian (Kej.1:26-28) } \\
\text { 2. } & \text { Markus (Mrk.10:46-52) }\end{array}$ \\
\hline & Aborsi & $\begin{array}{ll}\text { 1. } & \text { Yeremia (Yer.1:4-5) } \\
\text { 2. } & \text { Dokumen Konsili Vatikan II, Gaudium et Spes } \\
\text { (Kegembiraan dan Harapan) artikel } 51\end{array}$ \\
\hline & Hukuman mati & $\begin{array}{ll}\text { 1. Katekismes Gereja Katolik (KGK) } 2267 \\
\text { 2. Ensiklik Evangelium Vitæ (Injil Kehidupan) artikel } \\
27\end{array}$ \\
\hline & $\begin{array}{l}\text { Kesetaraan laki-laki dan } \\
\text { perempuan }\end{array}$ & $\begin{array}{ll}\text { 1. } & \text { Kejadian (Kej.2:18-23) } \\
\text { 2. Lukas (Luk.2:41-52) } \\
\text { 3. Katekismus Gereja Katolik (KGK) artikel 369, } \\
\text { artikel 371, artikel 372, artikel 2335 }\end{array}$ \\
\hline \multirow{6}{*}{$\begin{array}{l}\text { 3. Penanaman } \\
\text { rasa tanggung } \\
\text { jawab terhadap } \\
\text { keragaman } \\
\text { budaya pada } \\
\text { masyarakat } \\
\text { dunia. }\end{array}$} & $\begin{array}{l}\text { Kejujuran, keadilan, dan } \\
\text { kebenaran }\end{array}$ & $\begin{array}{l}\text { 1. Matius (Mat.20:1-16) } \\
\text { 2. Kisah Para Rasul (Kis.5:1-10) }\end{array}$ \\
\hline & $\begin{array}{l}\text { Hak dan kewajiban sebagai } \\
\text { warga negara }\end{array}$ & $\begin{array}{l}\text { 1. Dokumen Konsili Vatikan II, Gaudium et Spes } \\
\text { (Kegembiraan dan Harapan) artikel } 25 \text { dan } 76 \\
\text { 2. Dokumen Konsili Vatikan II, Dekrit Ad Gentes } \\
\text { (Kepada Bangsa-bangsa) artikel } 11 \\
\text { 3. Hasil Sidang Agung Gereja Katolik Indonesia } \\
\text { (SAGKI) } 1995\end{array}$ \\
\hline & $\begin{array}{l}\text { Membangun persaudaraan } \\
\text { sejati melalui kerja sama } \\
\text { antarumat beragama dan } \\
\text { berkepercayaan lain }\end{array}$ & $\begin{array}{ll}\text { 1. } & \text { Lukas (Luk.10:25-37) } \\
\text { 2. Surat pertama Yohanes (1Yoh.4:21) } \\
\text { 3. Dokumen Konsili Vatikan II, Nostra Ætate } \\
\text { (Pernyataan tentang Hubungan Gereja dengan } \\
\text { Agama-agama Bukan Kristen) artikel } 1 \text { dan } 2\end{array}$ \\
\hline & $\begin{array}{l}\text { Mengupayakan perdamaian } \\
\text { dan persatuan bangsa }\end{array}$ & $\begin{array}{ll}\text { 1. } & \text { Matius (Mat.5:9.21-25) } \\
\text { 2. } & \text { Dokumen Konsili Vatikan II, Gaudium et Spes } \\
\text { (Kegembiraan dan Harapan) artikel } 25 \text { dan } 76\end{array}$ \\
\hline & $\begin{array}{l}\text { Bersikap kritis terhadap } \\
\text { ideologi dan gaya hidup } \\
\text { yang berkembang dewasa } \\
\text { ini }\end{array}$ & $\begin{array}{l}\text { 1. Dokumen Konsili Vatikan II, Gaudium et Spes } \\
\text { (Kegembiraan dan Harapan) artikel 6, 60, 64, 73, } \\
\text { dan } 76 \\
\text { 2. Ensiklik Populorum Progressio (Pergerakan } \\
\text { Bangsa-bangsa) artikel } 21 \text { dan } 42\end{array}$ \\
\hline & $\begin{array}{l}\text { Gereja sebagai persekutuan } \\
\text { yang terbuka }\end{array}$ & $\begin{array}{ll}\text { 1. } & \text { Kisah Para Rasul (Kis.4:32-37) } \\
\text { 2. } & \text { Dokumen Konsili Vatikan II, Dekrit Ad Gentes } \\
\text { (Kepada Bangsa-bangsa) artikel } 10\end{array}$ \\
\hline
\end{tabular}




\begin{tabular}{|c|c|c|}
\hline & $\begin{array}{l}\text { Keutuhan lingkungan hidup } \\
\text { ciptaan Tuhan }\end{array}$ & $\begin{array}{l}\text { 1. Mazmur (Mzm.104:10-18.21.31) } \\
\text { 2. Kompendium Ajaran Sosial Gereja (ASG) no. } 466\end{array}$ \\
\hline & $\begin{array}{l}\text { Permasalahan yang dihadapi } \\
\text { dunia }\end{array}$ & $\begin{array}{l}\text { 1. Kejadian (Kej.1:26-28) } \\
\text { 2. Dokumen Konsili Vatikan II, Gaudium et Spes } \\
\text { (Kegembiraan dan Harapan) artikel } 1 \\
\end{array}$ \\
\hline & & 1. Rerum Novarum (Kondisi Kerja): Ensiklik Paus Leo \\
\hline & & 2. Quadragessimo Anno (Tahun Keempatpuluh): \\
\hline & & Ensiklik Paus Pius XI \\
\hline & & $\begin{array}{l}\text { 3. Mater et Magistra (Ibu dan Pengajar): Ensiklik Paus } \\
\text { Yohanes XXIII }\end{array}$ \\
\hline & & $\begin{array}{l}\text { 4. Pacem in Terris (Damai di Bumi): Ensiklik Paus } \\
\text { Yohanes XXIII }\end{array}$ \\
\hline $\begin{array}{l}\text { 4. Pengembangan } \\
\text { tanggung jawab }\end{array}$ & & $\begin{array}{l}\text { 5. Gaudium et Spes (Kegembiraan dan Harapan): } \\
\text { Konstitusi Pastoral Konsili Vatikan II }\end{array}$ \\
\hline terhadap planet & & $\begin{array}{l}\text { 6. Populorum Progressio (Kemajuan Bangsa-bangsa): } \\
\text { Ensiklik Paus Paulus VI }\end{array}$ \\
\hline & Ajaran Sosial Gereja (ASG) & $\begin{array}{l}\text { 7. Octogessima Adveniens (Tahun Kedelapanpuluh): } \\
\text { Surat Apostolik Paus Paulus VI }\end{array}$ \\
\hline & & 8. Evangelii Nuntiandi (Evangelisasi di Dunia \\
\hline & & Modern): Anjuran Apostolik Paus Paulus VI \\
\hline & & $\begin{array}{l}\text { 9. Redemptor Hominis (Sang Penebus Manusia): } \\
\text { Ensiklik Paus Yohanes Paulus II }\end{array}$ \\
\hline & & $\begin{array}{l}\text { 10. Laborem Exercens (Kerja Manusia): Ensiklik Paus } \\
\text { Yohanes Paulus II }\end{array}$ \\
\hline & & $\begin{array}{l}\text { 11. Sollicitudo Rei Socialis (Keprihatinan Sosial): } \\
\text { Ensiklik Paus Yohanes Paulus II }\end{array}$ \\
\hline & & 12. Centesimus Annus (Tahun Keseratus): Ensiklik Paus \\
\hline & & Yohanes Paulus II \\
\hline & & 13. The Participation of Catholics in Political \\
\hline
\end{tabular}

Tabel 3 mengungkapkan bahwa buku teks PAK Kurikulum 2013 menunjukkan dinamika pewartaan Gereja tentang nilai-nilai multikultural. Dinamika itu nampak dari digunakannya dokumen-dokumen Konsili Vatikan II, terutama dokumen-dokumen yang memiliki orientasi pewartaan ad extra atau inklusif. Dokumen-dokumen yang dimaksud adalah Nostra Ætate, Gaudium et Spes, Unitatis Redintegratio, dan Ad Gentes. Dengan kata lain, muatan nilai-nilai multikultural dalam buku teks PAK Kurikulum 2013 selaras dengan dinamika pewartaan Gereja tentang nilai-nilai multikultural. Sebuah penelitian juga menegaskan adanya keselarasan ini, terutama dalam penggunaan dokumen Nostra Ætate (Wijaya \& Gaudiawan, 2020).

Penggunaan dokumen Nostra Ætate secara khusus artikel 2 terdapat pada buku teks PAK Kelas XII. Pembahasan yang menggunakan basis dokumen Nostra Ætate artikel 2 ini menjelaskan tentang karakteristik agama-agama dan kepercayaan yang ada di Indonesia serta sikap mereka terhadap Gereja Katolik (Komisi Kateketik, 2017) secara cukup komprehensif. Penjelasan itu menegaskan bahwa Gereja Katolik tidak menolak segala apa pun yang baik dan benar yang terdapat pada agama-agama lain (Bakker, 1972). Akan tetapi, penjelasan ini nampak kurang otoritatif dan orisinal karena disusun penulis yang tidak memiliki kompetensi penuh.

Inkompetensi yang dimaksudkan adalah kenyataan bahwa penulis bagian ini bukanlah penganut atau mereka yang sungguh-sungguh memahami karakteristik, ajaran, dan sikap terhadap Gereja Katolik dari masing-masing agama. Para penulis menyusun materi itu dengan rujukan teks atau bukubuku yang terdapat dalam Daftar Pustaka. Akan tetapi, tetap harus ada yang dapat memastikan bahwa rujukan yang digunakan memberikan informasi secara tepat dan mendalam karena teks merupakan unsur agama yang paling mudah disalahgunakan (Kimball \& Nurhadi, 2003; Nelson-Pallmeyer, 2005). Kesulitan dalam menemukan pemahaman atas teks atau adanya kesulitan pembacaan terkadang menyebabkan distorsi pemahaman atas makna pesan agama yang sesungguhnya (Huda \& Hidayati, 
2019). Oleh karena itu, kepastian kebenaran informasi terkait agama-agama non-Katolik ini harus berada pada tataran pengawasan atau fungsi kontrol.

Buku teks PAK Kelas XII juga menempatkan dokumen Gaudium et Spes sebagai basis materi ajar yang bermuatan nilai-nilai multikultural. Penggunaan dokumen Gaudium et Spes sebagai basis ajaran Gereja bermuatan nilai-nilai multikultural menjadi suatu yang tidak terelakkan. Dengan kata lain, tanpa penggunaan dokumen ini, suatu ajaran Gereja belum dapat disebut bermuatan nilai-nilai multikultural.

Dalam konteks Indonesia, dokumen Gaudium et Spes mendorong umat Katolik untuk ikut serta secara aktif memancarkan terang baru kepada masyarakat dalam wujud pembelaan terhadap martabat manusia secara hakiki. Medan karya nyatanya adalah kondisi masyarakat Indonesia. Kenyataannya, sebagian besar penduduk Indonesia sedang berjuang untuk menemukan kehidupan yang lebih baik, membebaskan dari setiap penindasan dan memperjuangkan keadilan di bidang hak-hak asasi manusia, ekonomi, pendidikan dan di banyak sektor yang lain. Dalam misinya, Gereja harus menunjukkan fungsi profetis. Menurut Zuly Qodir (Qodir, 2009), kehadiran agama dengan misi profetik adalah bagian dari tanggung jawab di muka bumi yang penuh dengan tumpukan persoalan ini seperti kemiskinan, kebodohan, ketidakadilan, kekerasan, keterbelakangan, dan hal terkait lainnya. Fungsi profetis Gereja mewujud dalam memberi dorongan kepada kaum kecil karena "kegembiraan dan harapan, duka dan kecemasan orang-orang zaman sekarang, terutama kaum miskin dan siapa saja yang menderita, merupakan kegembiraan dan harapan, duka dan kecemasan para murid Kristus juga" (Gaudium et Spes artikel 1) (Hariprabowo, 2009).

Dialog dengan saudara-saudara Kristen Protestan mendapat perhatian dalam pembahasan pada buku teks PAK Kelas XII. Hal itu nampak dari penggunaan dokumen Unitatis Redintegratio. Dokumen ini menunjukkan bahwa Konsili Vatikan II adalah suatu turning point (titik balik) penting bukan hanya dalam sejarah Gereja Katolik, melainkan juga dalam sejarah Kekristenan secara umum (Noll, 2012). Jika dua konsili sebelumnya (Konsili Trente dan Konsili Vatikan I) sangat bernuansa penolakan terhadap Gereja Protestan (kontra-reformasi), Konsili Vatikan II justru dapat dibaca sebagai akhir kontrareformasi (Tavard, 1965).

Sejak dini umat Katolik harus mendapat penjelasan bahwa dialog, termasuk dengan saudarasaudara Kristen Protestan adalah suatu upaya untuk semakin mengenali jati dirinya sebagai pengikut Kristus. Menurut Michael Novak (Novak, 2017), secara khusus dokumen Unitatis Redintegratio menjadi suatu babak baru dalam sejarah Katolik untuk beranjak dari sebuah Gereja yang tertutup, menjadi Gereja yang terbuka, dari sebuah Gereja dengan teologi konservatif, triumfalistik, dan statis, menjadi Gereja dengan teologi terbuka pada diskusi, perbedaan, dan percakapan dengan orang beriman lain, termasuk saudara-saudara seiman dalam Kristus.

Ajaran-ajaran Gereja Katolik yang bermuatan nilai-nilai multikultural harus menemukan wujud konkretnya dalam aktivitas. Wujud konkret itu ada di dalam dokumen Ad Gentes. Buku teks PAK Kurikulum 2013 juga menggunakan dokumen ini dalam menyampaikan materi ajar bermuatan nilainilai multikultural. Substansi dokumen Ad Gentes adalah pernyataan Gereja bahwa luasnya konsep dan cakupan misi dan pewartaan Injil (evangelisasi) bukan hanya bertujuan untuk pertobatan dan persatuan dalam komunitas kristiani, melainkan bertujuan juga untuk menyebarkan nilai-nilai Kerajaan Allah. Dialog antar agama dapat menjadi aktivitas misioner spesifik yang melengkapi pewartaan dan pembentukan komunitas Kerajaan Allah yang ditandai adanya kondisi aman dan sejahtera (Dupuis, 2001).

Menurut dokumen Ad Gentes, dialog merupakan konsep yang menunjukkan kebaruan dalam aktivitas misioner pasca konsili. Dialog lahir dari visi Tuhan sendiri, yang berdialog dengan setiap individu untuk mengungkapkan kehendak penyelamatan-Nya. Tuhan menetapkan sejarah keselamatan bukan hanya untuk orang tertentu, melainkan bagi seluruh bangsa, bahkan agama ( $A d$ Gentes artikel 11). Tindakan Tuhan yang demikian harus menjadi inspirasi bagi Gereja dalam aktivitas misinya (Zago, 1984).

Melalui dialog, dokumen Ad Gentes mengajak umat Katolik menjadikan perekat sosial (social cement). Aktivitas misi dalam wujud dialog akan menumbuhkan kesadaran akan pentingnya 
pluralisme dan keadilan struktur sosial dalam mengekspresikan keyakinan baik intra maupun antaragama. Kesadaran ini akan mampu mewujudkan agama sebagai salah satu social cement dalam arti yang luas. Kesadaran ini perlu ditumbuhkan untuk menolak sikap yang bersendikan pada truth claim yang radikal dan fundamentalistik karena sikap ini akan lebih sering memunculkan agama sebagai faktor penyebab konflik (Jamil \& Djamil, 2007). Untuk itu, aktivitas misi Gereja harus senantiasa memberi tempat bagi perjumpaan dengan agama-agama lain dan budaya-budaya lokal.

Menurut dokumen Ad Gentes, menjadi Gereja bukan berarti sibuk dengan identifikasi terkait yang asli dan murni dalam Gereja dan menghapus segala macam unsur lain yang terdapat dalam budaya lokal. Aktivitas misi juga tidak perlu jatuh pada ideologisasi karakter sebagai umat Katolik yang seolah-olah unggul mengatasi semua identitas diri lainnya. Menjadi Gereja lebih ditentukan dari ekspresi pola bersikap dan berperilaku dengan 'tatasusila yang diterima berdasarkan iman' dalam perkataan dan perbuatan (Djunatan, 2017). Untuk itu, Gereja harus mau belajar dari masyarakat dunia dan dinamikanya. Dengan demikian, usulan sejumlah teolog supaya dokumen ini berganti nama menjadi 'Inter Gentes' (antar bangsa-bangsa) nampaknya masuk akal. Nama ini mengandung adanya gerak misi timbal-balik, yaitu bahwa Gereja tidak boleh menempatkan dirinya sebagai yang superior sehingga berhak mengajar (ecclesia docens), tetapi juga siap untuk belajar (ecclesia discens) (Sudiarsa, 2017).

Secara ringkas, analisis Dialektika pewartaan nilai-nilai multikultural Gereja dalam buku teks PAK Kurikulum 2013 dapat dijelaskan dalam tabel 4.

Tabel 4. Dialektika pewartaan nilai-nilai multikultural Gereja dalam PAK Kurikulum 2013

\begin{tabular}{|c|c|c|}
\hline Kecenderungan & Indikator & Tawaran Gagasan \\
\hline $\begin{array}{l}\text { Muatan nilai-nilai } \\
\text { multikultural dalam buku } \\
\text { teks PAK Kurikulum } 2013 \\
\text { selaras dengan dinamika } \\
\text { pewartaan Gereja tentang } \\
\text { nilai-nilai multikultural. }\end{array}$ & $\begin{array}{l}\text { Penggunaan dokumen- } \\
\text { dokumen Konsili } \\
\text { Vatikan II: Nostra Ætate, } \\
\text { Gaudium et Spes, Unitatis } \\
\text { Redintegratio, dan Ad } \\
\text { Gentes. }\end{array}$ & $\begin{array}{l}\text { Perlu upaya menumbuhkan kesadaran } \\
\text { untuk bersikap dan berperilaku dengan } \\
\text { 'tatasusila yang diterima berdasarkan } \\
\text { iman' dalam perkataan dan perbuatan } \\
\text { karena di level basis umat Katolik masih } \\
\text { bergumul dengan klaim-klaim kebenaran } \\
\text { yang keliru. }\end{array}$ \\
\hline $\begin{array}{l}\text { Buku teks PAK } \\
\text { Kurikulum } 2013 \text { memberi } \\
\text { penjelasan bahwa Gereja } \\
\text { Katolik tidak menolak } \\
\text { segala apa pun yang baik } \\
\text { dan benar yang terdapat } \\
\text { pada agama-agama lain. }\end{array}$ & $\begin{array}{l}\text { Aplikasi dokumen } \\
\text { Nostra Ætate artikel } 2 \\
\text { dalam wujud penjelasan } \\
\text { karakteristik agama- } \\
\text { agama dan kepercayaan } \\
\text { yang ada di Indonesia } \\
\text { serta sikap mereka } \\
\text { terhadap Gereja Katolik. }\end{array}$ & $\begin{array}{l}\text { Harus ada yang dapat memastikan bahwa } \\
\text { rujukan yang digunakan memberikan } \\
\text { informasi secara tepat dan mendalam } \\
\text { karena teks merupakan unsur agama } \\
\text { yang paling mudah disalahgunakan. }\end{array}$ \\
\hline
\end{tabular}

Demikian itu adalah contoh bagaimana buku-buku teks keagamaan memasukkan doktrin-doktrin tentang hal-hal yang bersifat non-keagamaan seperti masalah sosial, budaya, dan keragaman (diversity) (Berglund, 2020; Cornelio \& Aldama, 2020). Hal itu mengingatkan kita pada hermeneutika Ricoeur (Ricoeur \& Thompson, 1981), dalam hal buku teks ini dapat sampai pada proses idealnya, yaitu pembauran cakrawala. Pembauran cakrawala itu terjadi sudah sejak buku teks itu sendiri. Artinya, buku teks PAK Kurikulum 2013 menjadi titik jumpa sekaligus titik dialektis antara pengalaman keberagaman dari masing-masing penggunannya (para peserta didik dan pengajar) dengan dunia wacana yang ditawarkan buku tersebut. Strategi atau metode yang mengarahkan upaya mendaratkan gagasan teoretis-konseptual ke tataran praksis itu mengintensifkan dialektika pembauran cakrawala yang telah terjadi secara teoretis-konseptual ke tataran praksis dalam pengalaman nyata. Pada gilirannya, buku teks ini menjadi wacana yang hidup yang pada gilirannya menghasilkan pesan dan makna yang dalam tafsir hermeneutika Ricœur (Bologna, Trede, \& Patton, 2020; Ricoeur, 2013) berada 
pada ranah atau wilayah yang paling luas dan paling berjauhan dengan teks (buku teks), tetapi tetap berada pada horizon yang dipancarkan teks tersebut.

\section{Kesimpulan}

Analisis terhadap buku teks Pendidikan Agama Katolik dan Budi Pekerti (PAK) Kurikulum 2013 menunjukkan adanya muatan nilai-nilai multikultural di dalamnya. Berdasarkan analisis itu penelitian ini memiliki dua simpulan yang mengintisarikan ketercapaian tujuannya. Pertama, adanya ragam tema dan karakteristik multikultural dalam buku teks PAK Kurikulum 2013. Kedua, adanya dialektika dan cara Gereja Katolik menyelenggarakan pewartaan tentang nilai-nilai multikultural dalam buku teks PAK Kurikulum 2013.

Dengan menggunakan empat nilai inti (core values) multikultural sebagai indikatornya, analisis menunjukkan bahwa buku teks PAK Kurikulum 2013 memiliki 39,7\% Kompetensi Dasar yang bermuatan nilai-nilai multikultural. Prosentase ini cukup memadai dari sudut pandang kuantitas karena mencakup lebih dari sepertiga dari keseluruhan Kompetensi Dasar yang dimilikinya. Akan tetapi, dari sudut pandang kualitas, ragam tema tersebut masih perlu mendapatkan perhatian terkait kedalaman atau eksplorasinya.

Kedalaman secara kualitatif ini terkait dengan terjaganya keseimbangan antara unsur-unsur mendasar dari setiap agama dan kepercayaan yang mencakup sejarah dan konteksnya, refleksivitas dan tradisi, serta gerakan-gerakan pencerahan dalam penyampaiannya. Upaya mendalami ragam tema yang disajikan dalam materi ajar masih mengandalkan rujukan yang bersifat umum dan masih berkisar di permukaan. Materi yang mendalam membutuhkan rujukan yang lebih otentik dan otoritatif. Rujukan itu dapat berupa tokoh-tokoh agama dan kepercayaan yang memiliki kompetensi untuk menjelaskan agama dan kepercayaannya secara lebih mendalam. Sekurang-kurangnya, keterlibatan mereka dapat menjadi fungsi kontrol atas kualitas dalam arti kecukupan dan kedalaman informasi terkait agama-agama dan kepercayaan di luar Katolik. Pelibatan tersebut juga niscaya mencegah terjadi distorsi informasi dan kesalahpahaman akibat sumber-sumber informasi yang keliru atau tidak standar. Dengan kata lain, harus ada yang dapat memastikan bahwa rujukan yang digunakan terkait ajaran agama dan kepercayaan di luar Gereja Katolik itu memberikan informasi yang tepat dan mendalam karena teks merupakan unsur agama yang paling mudah disalahgunakan.

Buku teks PAK Kurikulum 2013 masih harus mendapat perbaikan, terutama terkait strategi yang diberikannya untuk mendaratkan hal-hal teoretis-konseptual itu ke tataran praksis. Tataran praksis yang dimaksudkan di sini adalah suatu kondisi di mana peserta didik atau siswa tidak hanya mendapatkan gagasan teoretis-konseptual, tetapi lebih daripada itu mendapatkan pengalaman langsung sehingga dapat merasakan secara personal nilai-nilai multikultural tersebut. Supaya kesesuaian itu terus dapat terjaga, otoritas fungsi pengawasan terhadap pendidikan agama harus memiliki kompetensi yang baik. Otoritas fungsi pengawasan dengan kompetensi yang baik akan memberi jaminan bahwa pendidikan agama dapat memberikan cakrawala pandang yang benar dan tepat kepada peserta didik.

\section{Referensi}

Abdullah, M. A. (2005). Pendidikan agama era multikultural-multireligius. Jakarta: Pusat Studi Agama dan Peradaban Muhammadiyah.

Aimonetti, J. W., \& Talley, C. (2021). Religious Exemptions As Rational Social Policy. Rich. L. Rev. Online, 55, 2560.

Ameny-Dixon, G. M. (2004). Why multicultural education is more important in higher education now than ever: A global perspective. International Journal of Scholarly Academic Intellectual Diversity, 8(1), 1-9.

Arnold, T. W. (1981). Sejarah Dakwah Islam (N. Rambe, Trans.). Jakarta: Widjaya.

Baidhawy, Z. (2005). Pendidikan agama berwawasan Multikultural. Jakarta: Erlangga.

Bakker, J. W. (1972). Piagam 'Nostra Aetate'Konsili Vatikan II; Tafsiran zaman kita, zaman dialog antar-agama. Yogyakarta: Kanisius.

Bennett, C. I. (1986). Comprehensive multicultural education: Theory and practice. Boston: Allyn and Bacon.

Berglund, J. (2020). The contribution of comparative studies to the international transfer and transformation in 
religious education. International Knowledge Transfer in Religious Education, 107.

Bologna, R., Trede, F., \& Patton, N. (2020). A Critical Imaginal Hermeneutics Approach to Explore Unconscious Infuences on Professional Practices: A Ricoeur and Jung Partnership. The Qualitative Report, 25(10), 34863518.

Cai, Y. (2014). Desiderium naturale vivendi Deum in Robert Bellarmine's Commentary on Summa theologiae. Gregorianum, 95(3), 511-534.

Clarke, G. W. (1973). Cyprian's Epistle 64 and the Kissing of Feet in Baptism. The Harvard Theological Review, 66(1), 147-152.

Clendenin, D. B. (n.d.). Many Gods, Many Lords: Christianity Encounters World Religions. Michigan: Baker Pub Group.

Cornelio, J., \& Aldama, P. K. (2020). Religious Diversity and Covenantal Pluralism in the Philippines. The Review of Faith \& International Affairs, 18(4), 74-85.

D'Costa, G. (1990). “Extra ecclesiam nulla salus” revisited. In Religious Pluralism and Unbelief: Studies Critical and Comparative. London: Routledge.

Daryanto, H. S. (2014). Siap menyongsong kurikulum 2013. Yogyakarta: Gava Media.

Dawson, C. (1929). Christopher Dawson progress and religion: An historical enquiry. London: Sheed and Ward.

Dein, S., Loewenthal, K., Lewis, C. A., \& Pargament, K. I. (2020). COVID-19, mental health and religion: an agenda for future research. Mental Health, Religion $\mathcal{E}$ Culture, 23(1), 1-9. https://doi.org/10.1080/13674676.2020.1768725

del Castillo, F., \& Alino, M. (2020). Religious Coping of Selected Filipino Catholic Youth. Religions, 11(9), 1-12. https://doi.org/10.3390/rel11090462

Denzinger, H. (1957). The sources of Catholic dogma. St. Louis: Herder.

Dermawan, A. (2002). Metodologi Ilmu Dakwah. Yogyakarta: Lembaga Studi Filsafat Islam.

DiNoia, J. A. (1992). The diversity of religions: a Christian perspective. Washington: Catholic University of America Press.

Dister, N. S. (1994). Pengalaman dan motivasi beragama: pengantar psikologi agama. Yogyakarta: Penerbit Kanisius.

Djunatan, S. (2017). Krisis Identitas Diri dan Kegiatan Misioner Gereja, Prosiding Seminar-Lokakarya Memperingati 50 tahun Ad Gentes. Bandung: Universitas Katolik Parahyangan.

Dulles, A. (1992). John Paul II and the new evangelization. America, 166(3), 52-63.

Dunch, R. (2002). Beyond cultural imperialism: Cultural theory, Christian missions, and global modernity. History and Theory, 41(3), 301-325.

Dupuis, J. (2001). Il cristianesimo e le religioni: dallo scontro all'incontro. Brescia: Queriniana.

Fornberg, T. (1995). The Problem of Christianity in Multi-Religious Societies Today: The Bible in a World of Many Faiths. New York: Edwin Mellen Press.

Hardianto, P. D. (2014). Pentingnya Pendidikan Interreligiusitas Di Sekolah Dasar. Jurnal Teologi (Journal of Theology), 3(1), 13-24.

Hariprabowo, Y. (2009). Misi Gereja Di Tengah Pluralitas Agama Dan Budaya. Jurnal Orientasi Baru, 18(1), 33-50.

Harjuna, M. (2019). Dialog Lintas Agama dalam Perspektif Hans Kung. Living Islam: Journal of Islamic Discourses, 2(1), 55-74.

Huda, M. T., \& Hidayati, N. (2019). Peran Komisi Hubungan Antar Umat Beragama Gereja Katolik dalam Membangun Dialog. Religi: Jurnal Studi Agama-Agama, 14(2), 194-216.

Jamil, M. M., \& Djamil, H. A. (2007). Mengelola konflik, membangun damai. Semarang: Walisongo Mediation Centre (WMC).

Kementerian Pendidikan dan Kebudayaan. (2015). Implementasi kurikulum 2013. Retrieved from https://www.kemdikbud.go.id/kemdikbud/dokumen/Paparan/Paparan Mendikbud pada Workshop Pers.pdf

Khozin, K. (2019). Desain Kurikulum Pendidikan Agama Islam Berperspektif Multikulturalisme Untuk Mengeliminasi Potensi Kekerasan. Proceeding Annual Conference on Islamic Education, 1(1), 36-44.

Kimball, C., \& Nurhadi. (2003). Kala Agama Jadi Bencana. Bandung: Mizan Media Utama.

Knitter, P. F. (1985). No other name?: A critical survey of Christian attitudes toward the world religions. New York: Orbis Books.

Komisi Kateketik. (2017). Pendidikan Agama Katolik dan Budi Pekerti: Belajar Mengikuti Yesus untuk SMP Kelas VII. Yogyakarta: Kanisius.

Koterski, J. (1993). Religion as the Root of Culture. In Christianity and Western Civilization: Christopher Dawson's Insights (pp. 15-35). San Francisco: Ignatius Press.

Kung, H. (1986). Christianity and World Religions: Paths to Dialogue with Islam, Hinduism, and Buddhism. New York: Orbis Books.

Küster, V. (2014). Intercultural Theology is a Must. International Bulletin of Missionary Research, 38(4), 171-176. 
https://doi.org/10.1177/239693931403800402

KWI. (2018). Konferensi Waligereja Indonesia, Nota Pastoral KWI 2018. Panggilan Hidup Menggereja dalam Hidup Berbangsa. Menjadi Gereja yang Relevan dan Signifikan. Jakarta: Penerbit Obor.

KWI. (2019). Konferensi Waligereja Indonesia, Dokumen tentang Persaudaraan Manusia untuk Perdamaian Dunia dan Hidup Beragama. Jakarta: Departemen Dokumentasi dan Penerangan KWI.

Lubac, H. de. (1967). The mystery of the supernatural. 1967: Herder and Herder.

Luthfi, D. (2019). Talqin Dzikir Sebagai Metode Dakwah Jama'ah Dan Fardiyyah. Khazanah Theologia, 1(1), 1-6. https://doi.org/10.15575/kt.v1i1.7125

Luwihta, A. D. (2016). Analisis nilai-nilai multikultural dalam buku teks siswa mata pelajaran Pendidikan Agama Islam (PAI) Kelas VII SMP. Universitas Islam Negeri Maulana Malik Ibrahim.

Mansur, M. (2010). Text Book Writing: Dasar-dasar Pemahaman, penulisan dan pemakaian Buku Teks. Yogyakarta: ArRuzz Media.

Martinez, F., Peattie, K., \& Vazquez-Brust, D. (2021). Faith in the future: On a mission to integrate sustainability into management theory and practice. Futures, 125, 102654. https://doi.org/10.1016/j.futures.2020.102654

McGrath, A. E. (1997). The Genesis of doctrine: A study in the foundations of doctrinal criticism. Vancouver B.C Canada: Regent College Publishing.

Mehfooz, M. (2021). Religious Freedom in Pakistan: A Case Study of Religious Minorities. Religions, $12(1), 51$. https://doi.org/10.3390/rel12010051

Meijer, R. (2010). Reform in Saudi Arabia: The Gender-Segregation Debate. Middle East Policy, 17(4), 80-100. https://doi.org/10.1111/j.1475-4967.2010.00464.x

Mochizuki, M. M. (2010). Rembrandt's Faith: Church and Temple in the Dutch Golden Age. The Catholic Historical Review, 96(4), 824-826.

Mujimin, M. (2006). Implementasi pembelajaran Tematik bagi Anak Berkelainan. JPK (Jurnal Pendidikan Khusus), 2(2), 32-43. https://doi.org/10.21831/jpk.v2i2.983

Mumtahanah, L. (2019). Nilai-nilai multikultural dalam pembelajaran pendidikan agama Islam di SDN 1 Balun Turi Lamongan. UIN Sunan Ampel Surabaya.

Murfi, A. (2016). Komparasi Nilai-Nilai Pendidikan Multikultural (Telaah Buku Teks Pelajaran Pendidikan Agama Islam dan Budi Pekerti Dengan Pendidikan Agama Kristen dan Budi Pekerti SMP Kelas VII Kurikulum 2013). UIN Sunan Kalijaga Yogyakarta.

Muzayanah, U. (2017). Indeks Pendidikan Multikultural dan Toleransi Siswa SMA/K di Gunungkidul dan Kulonprogo. Edukasi, 15(2), 294569.

Nelson-Pallmeyer, J. (2005). Is religion killing us?: Violence in the Bible and the Quran. New York: A\&C Black.

Noll, M. A. (2012). Turning points: Decisive moments in the history of Christianity. Michigan: Baker Books.

Novak, M. (2017). The open church. London: Routledge.

Nurhayati, E., Junaedi, D., \& Sahliah, S. (2020). Dakwah Islam Melalui Karya Sastra. Hanifiya: Jurnal Studi AgamaAgama, 2(2), 105-112. https://doi.org/10.15575/hanifiya.v2i2.7303

Oakes, G. (2003). Max Weber on Value Rationality and Value Spheres. Journal of Classical Sociology, 3(1), 27-45. https://doi.org/10.1177/1468795X03003001693

Piaget, J. (1968). Six psychological studies (A. Tenzer, Trans.). New Yor: Crown Publishing Group/Random House.

Pradana, R. P. (2017). Analisis Nilai-nilai Pendidikan Multikultural pada Buku Siswa Mapel Pendidikan Agama Islam dan Budi Pekerti Kurikulum 2013 SD Kelas 6. Tesis Program Magister Fakultas Tarbiyah dan Keguruan UIN Sunan Kalijaga ....

Qodir, Z. (2009). Gerakan Sosial Islam: Manifesto Kaum Beriman. Yogyakarta: Pustaka Pelajar.

Qodir, Z. (2013). Perspektif Sosiologi tentang Radikalisasi Agama Kaum Muda. Maarif, 8(1), 45-66.

Rahman, M. T. (2010). Pluralisme Politik. WAWASAN: Jurnal Ilmiah Agama Dan Sosial Budaya, 34(1), 1-13.

Ricoeur, P. (2013). Hermeneutics: writings and lectures. New Jersey: Wiley.

Ricoeur, P., \& Thompson, J. B. (1981). Hermeneutics and the Human Sciences. Cambridge: Cambridge University Press.

Rohman, M., \& Mukhibat, M. (2017). Internalisasi Nilai-Nilai Sosio-Kultural Berbasis Etno-Religi Di MAN Yogyakarta III. Edukasia: Jurnal Penelitian Pendidikan Islam, 12(1), 31-56.

Ruokanen, M. (1992). The Catholic doctrine of non-Christian religions: according to the Second Vatican Council. London: Brill.

Sosteric, M. (2021). Rethinking the Origins and Purpose of Religion: Jesus, Constantine, and the Containment of Global Revolution. Athens Journal of Social Sciences, 8, 1-20.

Sudiarsa, R. (2017). Gereja bagi Dunia: Memelihara Gelora Spirit Ad Gentes, Prosiding Seminar-Lokakarya Memperingati 50 tahun Ad Gentes. In Bandung: Unpar Press. Bandung: Universitas Katolik Parahyangan.

Tavard, G. H. (1965). The Church Tomorrow. New York: Herder and Herder. 
Titaley, J. A. (2009). Agama dan Kekerasan: Mencari Akar Kekerasan dalam Agama. In D. Supriatno, O. Dani, \& Daryatno (Eds.), Merentang Sejarah Memaknai Kemandirian: Menjadi Gereja bagi Sesama. Jakarta: BPK Gunung Mulia.

Truna, D. S. (2017). Pendidikan Agama Islam Berwawasan Multikulturalisme: Telaah Kritis Atas Muatan Pendidikan Multikulturalisme Dalam Buku Ajar Pendidikan Agama Islam (PAI) Di Perguruan Tinggi Umum Di Indonesia. Jakarta: Kementerian Agama RI.

Umro, J. (2018). Upaya Guru Pendidikan Agama Islam Dalam Mencegah Radikalisme Agama Di Sekolah. JIE (Journal of Islamic Education), 2(1), 89-108.

Weber, M. (1978). Economy and Society: An Outline of Interpretive Sociology, Volume 1. Berkeley, Los Angeles, London: University of California Press.

Wihardit, K. (2010). Pendidikan multikultural: suatu konsep, pendekatan dan solusi. Jurnal Pendidikan, 11(2), 96105.

Wijaya, A. I. K. D., \& Gaudiawan, A. V. E. (2020). Dampak Pembelajaran Reflektif Bagi Calon Guru Agama Katolik Terhadap Panggilan Keguruan. JPAK: Jurnal Pendidikan Agama Katolik, 20(1), 101-112.

Woolfolk, A. (2016). Educational psychology: Active learning edition. New York: Pearson.

Yaqin, A. (2021). Pendidikan Multi Kultural. Yogyakarta: LKiS.

Zago, M. (1984). Dialogo e missione. Presentazione Del Documento Della Plenaria Del, 147-153. and conditions of the Creative Commons Attribution (CC BY SA) license (https://creativecommons.org/licenses/by-sa/3.0/). 